\title{
THE EFFECTIVENESS OF KEGEL EXERCISE ON THE HEALING PROCESS OF EFFICIOTOMIC INFLAMATION AND PROLIFERATION PHASE ON POSTPARTUM MOTHER
}

\author{
Budiyarti, Yuliani', Adhaini, Rizka ${ }^{2}$ \\ ${ }^{1}$ Lecturer of University of Muhammadiyah Banjarmasin \\ ${ }^{2}$ Lecturer of University of Muhammadiyah Banjarmasin \\ Email:yuliani@stikesmb.ac.id
}

\begin{abstract}
Background: One of the actions that can be taken to accelerate labor and widen the birth canal is episiotomy. If the episiotomy wound does not receive treatment measures, such as exercise, it can cause some negative effects such as the time needed to heal the wound longer and the wound at high risk of infection. The purpose of this study is to prove the effectiveness of Kegel exercise on the healing process of episiotomy wounds in the inflammatory and proliferation phases of post-partum mothers.

Method: A quasi-experimental design was used on this quantitative research study. The research sample of post-partum mothers with episiotomy as many as 40 people were divided into two groups: 20 mothers of the intervention group and 20 mothers of the control group, using purposive sampling techniques and Mann Whitney analysis test.

Results: Kegel exercise was effective to increase the healing process of episiotomy wounds in postpartum mothers with statistic result $p$ value $0,000 \leq$ value $\alpha=0.05$.

Conclusion: Kegel exercise can be used as an alternative action that is easy and safe to accelerate the healing process of episiotomy wounds in post-partum mothers.
\end{abstract}

Keywords: Episiotomy, Inflammatory phase, Proliferation phase, Kegel exercise, wound healing. 


\section{Background}

Childbirth is a natural process that will take place by itself, but in the process every time there can be complications that risk endangering the mother and fetus and can cause the duration of the delivery process. One of the actions that can be taken to speed up the delivery process is an episiotomy (Astuti, 2015). An episiotomy is an incision in the perineum to widen the space in the outlet or birth canal to facilitate and accelerate the birth of a baby. In addition to widening the birth canal episiotomy is also often done to control the rupture of the birth canal so that it facilitates and accelerates the process of wound healing (Manuaba, 2012). Episiotomy wound healing takes weeks to years depending on health conditions and treatment of the perineum itself.

The World Health Organization (WHO) outlines the incidence of perineal rupture in 2009 of 2.7 million cases and this figure is expected to increase in 2050 which will reach 6.3 million cases. The Ministry of Health of the Republic of Indonesia in 2013 released total data of spontaneous labor as many as 1,951 and of the total spontaneous deliveries found $75 \%$ of mothers experienced perineal rupture, where $57 \%$ of mothers received perineal hetting due to episiotomy as much as $28 \%$ and spontaneous perineal tears as much as $29 \%$.

$$
\text { Brunner \& Suddarth (2015), }
$$
described when the perineum ruptures, the wound healing process occurs in 3 phases, namely the inflammatory phase which takes place from day 0 to day 3 , where in this phase blood vessels dilate around the wound, local erythema, edema, heat, discomfort and throbbing sensation around the wound; then proceed to the proliferation phase where in this phase new tissue growth occurs through three stages namely granulation, wound contraction and epithelialization which take place on days 414. The final phase is the phase of maturation that occurs after epithelialization is completed, where the new tissue undergoes remodeling or maturation to increase the strength of the scar tissue strain. This phase can last up to 2 years.

Farrag R.E, Eswi A.S, \& Badran H. (2016), explained that the delay in the process of wound healing episiotomy perfase can cause pain so that mobilization and daily living activities are disrupted, blood circulation is not smooth so that it reduces the effectiveness of the body to do the wound healing process which results in a high risk of infection. One effort that can be done to accelerate the process of healing episiotomy wounds is by doing kegel exersice. Kegel exersice is an exercise that is 
done actively on the muscles of the kegel or pubococcygeal muscles, where the muscle groups that help hold the organs in the pelvic area to remain in place. Besides kegel exercise is useful for repairing pelvic floor muscles and muscles of the abdominal wall so that blood flow is flowing which ultimately impacts on the acceleration of the wound healing process that occurs in the perineum. Kegel exercise will help speed up the process of healing the perineal wound by alternating contractions and relaxation of the pelvic floor muscles, expediting blood circulation to the perineum and strengthening the muscles of the urethral sphincter and anal sphincter (Shinde. N, Bhardwaj. S, Deepali. H, Khatri. S, 2013).

The above statement is in line with Reeder (2011), which elaborates Kegel exersice can be done to speed up the healing time of the perineal wound and is also strengthened by the results of D. E Martini's research. (2015), that post-partum mothers with perineal wounds (episiotomy) who performed Kegel exersice showed the acceleration of the time of the wound healing process.

The South Kalimantan Provincial Health Office outlines that on 2017 there are $4.67 \%$ mother (patient) who experienced perineal rupture. Data obtained from RSUD Dr. H.M.A.S.B total number of normal deliveries in 2018 was $75.34 \%$, from the total it was found that $62.36 \%$ of mothers received episiotomy, so it can be concluded that up to now episiotomy is still frequently performed on maternity care, which if no proper care is taken afterwards it will have an impact on the increased incidence of post partum maternal morbidity which results in length of day of care. Preliminary study conducted in February 2019 to 10 post partum mothers by interview obtained $70 \%$ of maternal mothers received episiotomy which resulted in the post partum mothers experiencing obstacles in mobilizing and daily living activities while in maternity care, unable to make maximum care to their baby, and increasing day care so that adds to the financial burden that must be removed.

Based on the description above if the episiotomy wound does not get proper treatment measures such as doing certain exercises, then many negative effects are caused. In general, research on the theme of Kegel Exercise and the process of wound healing in postpartum mothers, especially in South Kalimantan has never been done, so based on the description, a study aimed to prove the effectiveness of Kegel Exercise on the healing process of episiotomy wounds in the inflammatory phase and proliferation in postpartum mothers.

\section{Research Method}


This type of research is a quantitative study with a quasi experimental design posttest only non-equivalent control group. The sample was 40 post partum mothers who received episiotomy as many as 40 people divided into two groups: 20 mothers in the intervention group and 20 mothers in the control group. In the intervention group, the post partum mothers performed kegel exercises 6 hours after giving birth by contracting the pelvic muscles, then holding the contraction for up to 10 seconds and relaxing it for 10 seconds. Post partum mothers will repeat the process up to 10 sets with a frequency of 3 times a day. Then daily observations were made on episiotomy wounds to see signs of the wound healing process of the inflammatory and proliferation phases, whereas post partum mothers in the control group were not given Kegel exercise intervention but were still observed daily on episiotomy wounds to see signs of wound healing process of the phase of inflammation and proliferation. The inflammatory phase is observed from day 1 to day 3 including signs of dilatation of blood vessels around the wound, local erythema, edema, heat and discomfort around the wound and throbbing around the wound. Then proceed with observing the signs in the proliferation phase on day 4 to range 15 days including bright red granulation tissue, the base of the wound appears constricted, no blood comes out of the wound, both edges of the wound begin to close, formed scar tissue covered by new epithelial cells grow on the white, red and semi-transparent wound surface.

The sampling technique used is purposive sampling with non probabilty sampling analysis test, namely the Mann Whitney test. A research must pay attention to the ethical principles of research as a form of sense of responsibility towards efforts to recognize and defend human rights as part of a study. This study passed an ethical test and received a certificate worthy of research from the ethics committee of the Muhammadiyah University, Banjarmasin. 


\section{Research Result}

The results of the study can be seen in the following table:

Tabel 1. Characteristics of Post Partum Mothers

\begin{tabular}{|c|c|c|c|}
\hline \multirow[b]{2}{*}{ No } & \multirow[b]{2}{*}{ Characteristics } & \multicolumn{2}{|c|}{ Jumlah } \\
\hline & & $\begin{array}{c}\text { Frequency } \\
\text { (Person) }\end{array}$ & $\begin{array}{c}\text { Percentage } \\
(\%)\end{array}$ \\
\hline 1. & Ages 21-25 y.o. & 12 & 30 \\
\hline 2. & Ages 26-30 y.o. & 20 & 50 \\
\hline 3. & Ages $31-35$ y.o & 8 & 20 \\
\hline \multicolumn{2}{|r|}{ Total } & 40 & 100 \\
\hline 1. & Basic Education & 13 & 32,5 \\
\hline 2. & Middle Education & 24 & 60 \\
\hline 3. & Higher Education & 3 & 7,5 \\
\hline \multicolumn{2}{|r|}{ Total } & 40 & 100 \\
\hline 1. & Working & 9 & 22,5 \\
\hline 2. & Not working & 31 & 77,5 \\
\hline \multicolumn{2}{|r|}{ Total } & 40 & 100 \\
\hline
\end{tabular}

Table 1. found that most postpartum mothers are 20 people (50\%) aged 26-30 years, most of them are 24 people $(60 \%)$ have secondary education and most of them are 31 people (77.5) do not work

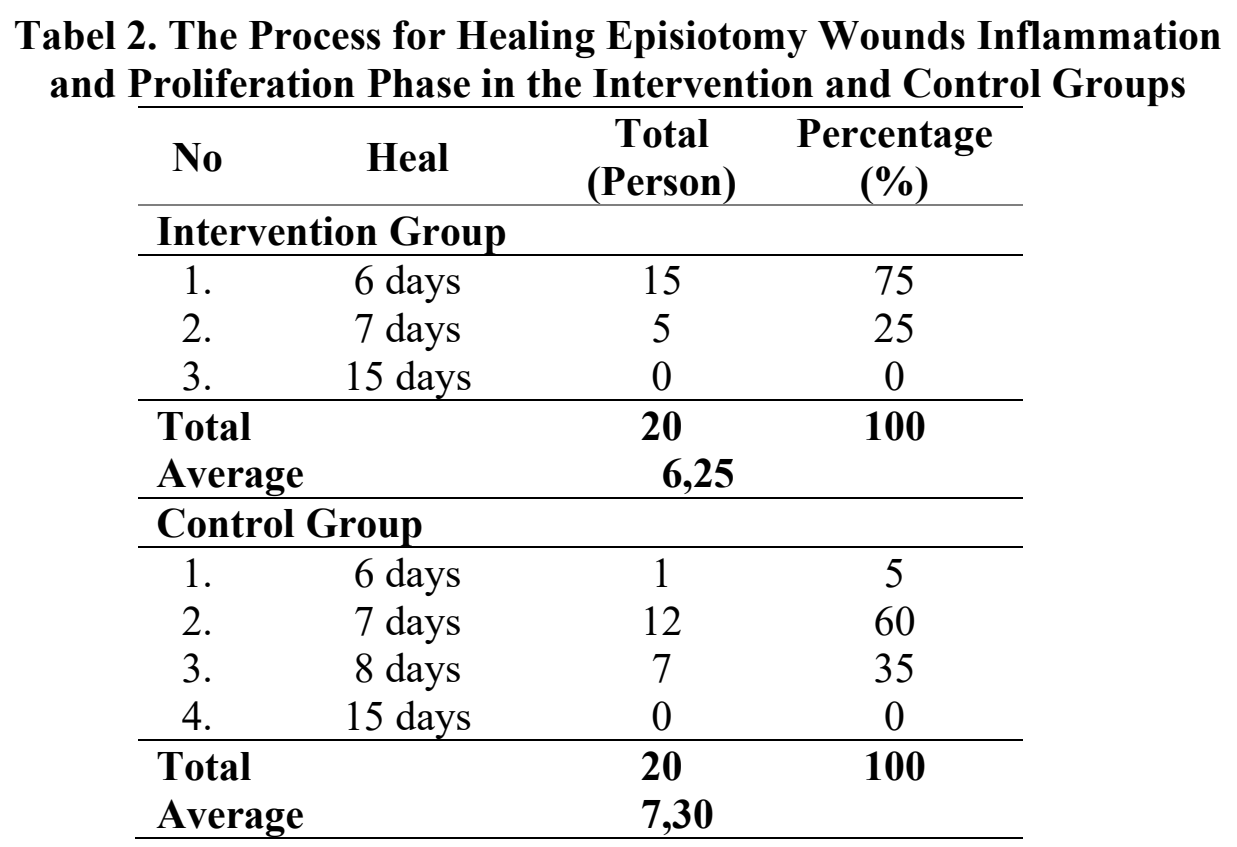

Table 2 shows the average duration of episiotomy wound healing in the inflammatory phase and postpartum maternal proliferation in the intervention group, 6.25 days and in the control group 7.30 days, so it can be concluded that the healing process of the inflammatory phase episiotomy wound and postpartum maternal proliferation in the group given Kegel exercise intervention 1 day faster than in the postpartum control group. 
Tabel 3. The Effectiveness of Kegel Exercise on the Process of Healing Episiotomy Wounds Inflammatory and Proliferation Phases

\begin{tabular}{lr}
\hline & \multicolumn{1}{c}{ Results } \\
\hline Mann-Whitney U & 42,500 \\
$Z$ & $-4,609$ \\
Asymp. Sig. (2-tailed) &, 000 \\
Exact Sig. [2*(1-tailed Sig.)] &, $000(\mathrm{a})$ \\
\hline
\end{tabular}

Table 3 shows the $\mathrm{p}$ value $=0,000<\alpha(0.05)$, so it can be concluded that Kegel Exercise is effective to accelerate the healing process of episiotomy wounds in the inflammatory phase and proliferation.

\section{Discussion}

The process of healing episiotomy wounds in the inflammatory phase and proliferation in postpartum mothers can be influenced by many factors, including factors characteristic of postpastum mothers such as age, level of education, occupation and parity.

Age

The results showed that the age of the majority of postpartum mothers in this study was 26-30 years. Hidayat \& Uliyah (2012), describing age is one of the factors that influence the wound healing process because the speed of cell repair takes place in line with the growth or maturity of a person's age.

$$
\text { Ministry of Health R.I. (2019) }
$$
describes the age of 26-30 years can be categorized into a healthy reproductive age, where at that age all organs are still functioning properly, so that the repair process of damaged body cells does not experience many obstacles.

Age of postpartum mothers who are in the range of 20-30 years, has a positive impact on the process of wound healing where at that age the body's metabolic rate is at its peak so that the organs are still functioning optimally, the reproductive system still has good circulation so that the inflammatory response takes place with quickly when there is injury, the collagen tissue becomes soft, the growth of new skin cell tissue does not require a long time and the scar tissue becomes elastic so the wound healing process from phase to phase takes place properly. But on the contrary as we get older, the aging process continues where the body will experience changes that cause involution and tissue degradation and all organs of the body experience deterioration so that the process of forming new cells becomes slower, most damaged cells are not replaced by new cell. This has resulted in the slow process of wound healing. 
The above description is in line with Smeltzer (2011), that wound healing occurs faster at a young age than at an old age because the function of tissue union in the skin has decreased due to age. The above is also supported by Berghell V, Baxter J.K, \& Chauhan S.P (2012), which describes that age can interfere with all stages of wound healing because as a person ages, vascular changes occur that can interfere with blood circulation to the injured area so that the wound does not get enough oxygen and nutrient intake is very important for the process of cell regeneration, which has an impact on the length of the wound healing process.

\section{Level of education}

The results showed that the majority of postpartum mothers have secondary education levels. By obtaining postpartum secondary education, mothers can develop their abilities and improve their intellectual abilities, where the two things above greatly affect their insights and ways of thinking which will later be reflected in daily behaviors and actions, both in behaviors and actions that can be seen directly and in terms of decision making. Education level is one of the factors that influence the perception of postpartum mothers to more easily accept something new. The same thing was stated by Maryam (2011), where the higher the level of one's education, the greater the opportunity to behave positively and have a good perception of something that is faced.

The statement above is in line with the results of research Suwarno, et al. (2014), mothers who have senior secondary education have positive behavior in terms of seeking treatment to speed up the healing process. Furthermore, it was also reinforced by Satino and Setyorini (2014) who stated that the behavior displayed by a person was directly proportional to the level of education.

Based on the description above, it can be concluded that the higher level of education a person has, the easier the person is to receive information which will ultimately be reflected in positive behavior.

\section{Occupation}

The results showed that most postpartum mothers did not work. Mothers who do not work mostly spend their time at home and only carry out routine household activities so there is a great opportunity to focus more on taking care of themselves. Conversely mothers who have jobs, because work in general is an activity that can take up one's time and attention so that sometimes there is a shift of focus from certain things.

The above description is in line with Said (2015), where work can divert 
someone's attention from something that is felt, because a dense activity can take up a lot of time and attention so that one does not have many opportunities to focus more on one thing.

In addition, mothers who have jobs will be more active outside the home and will interact more with other people which can cause most of the time spent with work and do not have the opportunity to just do and think about one thing.

The Process for Healing Episiotomy Wounds Inflammation and Proliferation in the Intervention and Control Groups.

The length of time needed for the healing process of the episiotomy wound of the inflammatory and proliferation phase in the postpartum maternal intervention group mostly lasts for 6 days, where the episiotomy wound that is experienced is in grade II, namely the wound on the vaginal mucosa, the front vulva, the skin to the perineal muscles so action is needed to accelerate the wound healing process. The acceleration of the process depends on several things including keeping the vaginal infection from happening, sewing skills (the injured muscles must be rearranged according to function and pathway) and avoiding many incisions in blood vessels and nerve cells, because if cut off, the vessels blood will not form again.

Manzanares S, Cobo D, MorenoMartines M.D, Sanchez-Gila M, \& Pineda A. (2013), describe the process of wound healing starting from the occurrence of injury to the body, where the process consists of 3 phases. The first phase is the inflammatory phase which lasts from day 0 to day 3 , where in this phase there is dilation of blood vessels around the wound, local erythema, edema, heat, discomfort and throbbing around the wound, then the proliferation phase continues, where in this phase new tissue growth occurs through three stages namely granulation, wound contraction and epithelialization which take place on days 4-14, and the last phase is the maturation phase that occurs after epithelialization is completed, where the new tissue undergoes remodeling or maturation to increase the strength of the strain scarring that can last up to 2 years.

One action that can be done to speed up the phases of the wound healing process is Kegel Exercise. In this study the postpartum mother's intervention group performed Kegel exercises 10 times in 1 day where every 1 time the exercise was carried out with a total of 10 sets. Then on the first day until the 3rd day post episiotomy observations were made on the wound to see the signs of the inflammatory phase and the 
data obtained dilated blood vessels around the wound, there were local erythema, edema, burning sensation around the wound, postpartum mothers complained of feeling uncomfortable and throbbing sensation around the wound. On the 4th day up to the 15 th day, observation is continued to see the signs of the proliferation phase. The data obtained from the healing phase of the proliferation wound lasted until the 6th day where the granulation tissue began to grow bright red, the base of the wound appeared to constrict and did not bleed easily, both edges of the wound seemed to be close together, scar tissue formed and it appeared that new epithelial cells had grown above the wound surface.

This proves that Kegel exercise intervention can help speed up the wound healing process 1 day compared to postpartum mothers who do not do Kegel exercises. The foregoing can occur because when doing Kegel exercises the pelvic floor muscles and perineal organs actively perform physical movements that can improve circulation and facilitate blood flow. This causes the supply of oxygen and nutrients smoothly to the damaged organ so that it can accelerate the wound healing process. The above description is supported by El Hamid A.A, Azzam H.F, Ismail G.M, \& Gaafar H.M. (2012), where Kegel exercises performed by the mother during childbirth can accelerate the healing process of perineal wounds and are also strengthened by Donmez. S \& Kavlak. O (2015), which outlines kegel exercises very effectively done in the postpartum period in order to accelerate the healing of perineal wounds.

In the control group the wound healing process lasted for 7 days (1 day longer than the group that performed Kegel exercises). The situation is due to the lack of movement of postpartum mothers so that it affects blood circulation to the perineum and is at risk of infection, where the infection does not only inhibit the wound healing process but can continue in the process of destruction of supporting cell tissue which results in an increase in the size, length and depth of the wound.

The Effectiveness of Kegel Exercise on the Process of Healing Episiotomy Wounds Inflammatory and Proliferation Phases.

In this study, there were differences in the duration of episiotomy wound healing in postpartum mothers who performed Kegel exercises and those who did not, whereas postpartum mothers who performed Kegel exercises faster 1 day in the wound healing process, so it can be concluded that Kegel Exercise was effective in accelerating the process of healing episiotomy wounds. inflammatory and proliferation phase. Kegel 
exercise is a physical exercise that is actively carried out by contracting and relaxing the pelvic floor muscles in the postpartum period so that it can maintain the fading of the muscles at the base of the hip bones, strengthen the vaginal and surrounding muscles (parineal) which will later improve circulation.

The movements that are performed while performing Kegel exercises are all active movements that cause the pelvic floor muscles to tighten so that the muscles contract and relax which have an impact on the smooth flow and local circulation which is very important in supplying oxygen and nutrients needed for regeneration cells, help reduce edema of the wound so that it can reduce discomfort in the perineum which will eventually speed up the wound healing process in the perineum.

The results of this study are also in line with Brayshaw (2008), which outlines that most postpartum mothers who exercise Kegel exercises have accelerated the process of perineal wound healing, and were also strengthened by Ali HALF (2015), where Kegel exercises can help increase contractions and relaxation of pelvic floor muscles thereby accelerating wound healing and decreasing discomfort in the perineal wound. Another study from Khusniyati E \& Purwati H. (2018), described 50\% of postpartum mothers who performed Kegel exercises experienced a more rapid wound healing process.

\section{Conclusion}

Kegel exercise can be used as an alternative action that can be done to accelerate the wound healing process in postpartum mothers who get episiotomy. The health workers can make Kegel Exercise as an independent intervention when implementing nursing care for postpartum mothers with episiotomy.

\section{References}

Ali, H.A.L.F. (2015). Effects of Prenatal Perineal Massage and Kegel Exercise on the Episiotomy Rate. IOSR Journal of Nursing and Health Science (IOSRJNHS). Volume 4, Issue 4 Ver.VII Diakses tanggal 14 September 2019 dari http://www.iosrjournals.org

Astuti, (2015). Asuhan Nifas \& Menyusui. Jakarta: Erlangga.

Berghell, V, Baxter, J.K \& Chauhan, S.P. (2012). Evidence Based Labor and Delivery Management. American Journal of Obstetri \& Gynecology, 199,445-454.

Brayshaw, Eileen. (2008). Senam Hamil dan Senam Nifas. Jakarta: EGC.

Brunner \& Suddarth. (2015). Keperawatan Medikal Bedah. Jakarta: EGC.

D. E Martini. (2015). The Effectiveness of Kegel Exercise on Acceleration of Wound Healing. Surya Journal Vol. 1 No 03. Desember 2015. Diakses tanggal 21 September 2019. Dari http://stikesmuhla.doi.org/18.1256/121 5.

Donmez, S \& Kavlak, O. (2015). Effect of Perineal Massage \& Kegel Exercise on the Intgrity of Postnatal Perineal. Journal Health in SciRes. 495-505. Diakses tanggal 14 September 2019. 
Dari

hhttp://dx.doi.org/10.4236/health.201 5.74059.

El Hamid, A.A, Azzam, H.F, Ismail G.M, \& Gaafar H.M. (2012). Effect of $a$ Structured Antenatal Kegel Exercises Protocol on Labor Progress Among Woman Attending Postnatal Clinics. Egytian Nursing Journal. 3.20902106. Diakses tanggal 5 September 2019.

Dari:

http://dx.doi.org/10.1111/j.13652702.2010.03297.x

Farrag, R.E, Eswi, A.S, \& Badran, H. (2016). Effect of Postnatal Kegel Exercises on Episiotomy Pain and Wound Healing Among Primiparous Women. Journal of Nursing and Health Science (IOSR-JNHS). Volume 5, Issue 3 Ver. III, PP 24-31. Diakses tanggal 14 September 2019 dari www.iosrjournals.org

Hidayat \& Uliyah. (2012). Konsep Dasar Manusia. Surabaya: Health Book Publising.

Khusniyati E \& Purwati H. (2018). Influence of Kegel Exercise on Duration of Healing Perineal to Women Postpartum. Jurnal Kesehatan Ibu dan Anak Vol.12, No.2, Nov 2018, Diakses tanggal 1 September 2019. Dari http://medianeliti.com pp. 93 99 Doi: 10.29238/kia.v12i2.147

Manuaba. (2012). Pengantar Kulah Obstetri. Jakarta: EGC.

Manzanares, S, Cobo, D, Moreno-Martines, M.D, Sanchez-Gila M, \& Pineda A. (2013). Risk of Episiotomy and Perineal Laceration Recurring after First delifery. Birth. 40, 307-311. Diakses tanggal 21 September 2019. dari http://dx.doi.org/10.1111/birt.12077

Maryam, (2011). Pengaruh Tingkat Pendidikan Wanita Usia Subur terhadap Perilaku Sadari. Naskah Publikasi Yogyakarta: UGM.

Reeder, Sharon J. (2011). Maternity Nursing: Family, Newborn and
Womens Health Care. Vol 1 \& 2. Ed 18. Lippincott.

Said, N, Kanine, E, Bidjuni, H. (2015). Hubungan Karakteristik dengan Kecemasan Ibu Primigravida di Puskesmas Tuminting. E journal Keperawatan (e-Kep). 3(2): 1-8. Diakses tanggal 21 September 2019. Dari http://medianeliti.com.

Shinde. N, Bhardwaj. S, Deepali. H, Khatri, S. (2013). Role of Kegels Exercise on Post Partum Perineal Fitness: Randomised Control Trial. Romanian Journal Of Physical Therapy/Revista Romania De Kinetot. Vol. 19 Issue 31. Diakses tanggal 14 September 2019. Dari

http://connection.ebschohost.com/c/art icles/90602719/rule-kegelspostpartum-perineal-fitnessrandomised-control-trial

Smeltzer \& Bare's (2011). Textbook of Medical Surgical Nursing. Vol. 1\&2. Ed 4. Australia/New Zeland.

Suwarno, Sartohadi, J, Sunarto, Sudharta D. (2014). Kajian Pengaruh Pendidikan terhadap Perilaku Masyarakat. Jurnal Geodukasi Vol. III No. 1. Diakses tanggal 21 September 2019. Dari http://medianeliti.com 